\title{
Protected Entree Design for Big Data Knowledge in Cloud
}

\author{
R.Kavitha, G.Kavitha, S. R. Srividhya
}

\begin{abstract}
Because of the trouble and limit, cryptography to a cloud is to be a standout amongst the best properties for huge information stockpiling and access. Anyway confirming the entrance authenticity of a client and safely refreshing cryptography in the cloud dependent on another entrance approach chosen by the information proprietor are likewise basic difficulties to make cloud-based enormous information stockpiling down to earth and dynamic. In this paper, we propose a safe and access control dependent on NTRU cryptosystem for huge information. Our procedure enables the cloud server to productively refresh the cryptography when another entrance arrangement is distinguished by the information proprietor, who is additionally ready to confirm the update to counter against duping practices of the cloud. It conjointly allows the information proprietor and qualified clients to successfully confirm the authenticity of a client for getting to the information, and a client to approve the data given by various clients to legitimate plaintext recuperation.
\end{abstract}

Keywords : Cryptanalysis, Randomized Algorithms

\section{INTRODUCTION}

Most existing methodologies for verifying the re-appropriated immense information in mists are bolstered either ascribed based encryption (ABE) or mystery sharing.[1] ABE based methodologies give the Flexibility for an information proprietor to predefine the arrangement of clients who are qualified for getting to the information anyway they experience the ill effects of the high unpredictability of productively refreshing the entrance strategy and cipher text [2]. The NTRU cryptosystem is a kind of cross section based cryptography and its security depends on the most brief vector issue (SVP)[3][4][5] in . NTRU is an open source open key cryptosystem that utilizes cross section based cryptography to scramble and decode information grid . The significant favorable circumstances of NTRU are quantum registering assault obstruction and lighting quick calculation ability. Be that as it may, NTRU experiences the issue of decoding disappointments[6]

\section{II.PURPOSE OF THE PROJECT}

We initially propose an improved NTRU cryptosystem to conquer the unscrambling disappointments of the first

\section{Revised Manuscript Received on July 22, 2019.}

R.Kavitha, Department of Computer Science and Engineering, Bharath Institute of Higher Education and Research, Chennai. Email: kavis_happy@yahoo.co.in

G.Kavitha, Department of Computer Science and Engineering, Bharath Institute of Higher Education and Research, Chennai. Email: kavithag90@gmail.com

S.R. Srividhya, Department of Computer Science and Engineering, Bharath Institute of Higher Education and Research, Chennai. Email: vidhyasrinivasan1890@gmail.com
NTRU[7][8]. At that point we structure a safe and irrefutable plan dependent on the improved NTRU and mystery sharing for huge information stockpiling. The

cloud server can legitimately refresh the put away cipher text without decoding dependent on the new access strategy indicated by the information proprietor, who can approve the update at the cloud. [9] The proposed plan can check the mutual mystery data to keep clients from bamboozling and can counter different assaults, for example, the intrigue assault.[10] It is likewise regarded to be secure as for quantum processing assaults due to NTRU.

\section{EXISTING SYSTEM}

These days, we can get to the information from the cloud without the verification, of the client.[11] As an information proprietor commonly does not reinforcement its information locally in the wake of re-appropriating the information to a cloud, it can only with significant effort deal with the information put away in the cloud.[12] In addition, as an ever increasing number of organizations and associations are utilizing mists to store their data, it ends up being also trying and basic to manage the issue of access strategy. [13]

\section{A. Disadvantage of Existing System:}

$>$ Leakage of basic data isn't taken care of.

$>$ Tampering of information might be conceivable

$>$ Personal data are not verify

$>$ Communication isn't ensured

\section{PROPOSED SYSTEM}

$>$ We propose another NTRU decoding methodology to beat the unscrambling disappointments of the first NTRU without decreasing the security quality of NTRU.

$>$ We propose a safe and irrefutable access control plan to secure the huge information put away in a cloud. [14][15]

$>$ The plan can check a client's entrance authenticity and approve the data given by different clients to address plaintext recuperation.[16][17]

$>$ We devise a proficient and irrefutable strategy to refresh the cryptosystem put away in mists without expanding any hazard when the entrance approach is powerfully changed.[18] 


\section{MODULES DESCRIPTION}

The list of modules in our project is:

$>$ ADMIN

$>$ DATA OWNER

$>$ USER

\section{VI . FLOW CHART DIAGRAM}

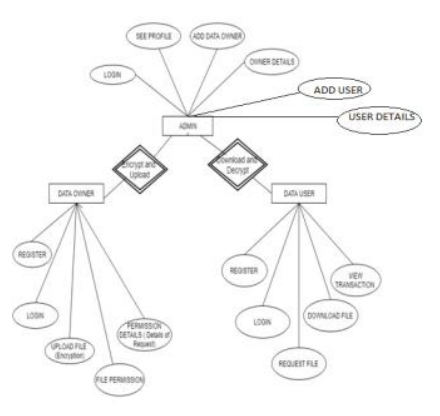

\section{A. Module 1: Admin}

- Admin module incorporates the login page at first. [19]to[ 30]

- The administrator has a different record to which he needs to login so as to check the data contained in the record.

- Once signed in, the administrator can see and screen every one of the profiles that are available in the cloud. [31] to [35

- The administrator will probably observe every one of the subtleties of the information proprietor like username, email, the information put away by him and his exchanges.

- The administrator approaches all the client subtleties which incorporates the equivalent username, email and the solicitations made by him for acquiring information.

\section{B. Module 2: Data Owner}

- A information proprietor needs to initially enlist for a record on the cloud.

- Once enlisted, he can login to his cloud record and begin utilizing it for capacity.

- The information proprietor would then be able to transfer documents to his record which will at that point be scrambled by the security arrangement refreshed by him.

- This module additionally incorporates the authorization demands gotten by the information proprietor from the client for getting to the record.

- The information proprietor will have the consent subtleties like the subtleties of the client mentioning it and the information which is mentioned[36]

\section{Module 3: User}

- The client needs to enlist for a record on the cloud. 38]to[40]
- He can then login to his cloud to get to the cloud information.

- The client sends a record solicitation to the information proprietor, mentioning for consent to get to his information.

- Once the solicitation is acknowledged by the information proprietor, utilizing the key the client can decode the information and download it for his use. [41]

- The client can see all his exchange subtleties, similar to the solicitations sent by him, the solicitations acknowledged by the information proprietor and the records allowed to the client.[42]

\section{CONCLUSION}

For as long as decades a client can get to cloud for sparing the information. In this undertaking, client can verify their information put away in the cloud by utilizing the NTRU Cryptosystem with the encryption and unscrambling process. While demand for the information download the client will sent the protected id to client who needs to download with the entrance of the mail. Our plan enables the information proprietor to progressively refresh the information get to approach and the cloud server to effectively refresh the comparing redistributed ciphertext to empower proficient access authority over the enormous information in the cloud.

\section{REFERENCES}

[1] Kumaravel A., Rangarajan K.,Algorithm for automaton specification for exploring dynamic labyrinths,Indian Journal of Science and Technology,V-6,I-SUPPL5,PP-4554-4559,Y-2013

[2] P. Kavitha, S. Prabakaran "A Novel Hybrid Segmentation Method with Particle Swarm Optimization and Fuzzy C-Mean Based On Partitioning the Image for Detecting Lung Cancer" International Journal of Engineering and Advanced Technology (IJEAT) ISSN: 2249-8958, Volume-8 Issue-5, June 2019

[3] Kumaravel A., Meetei O.N.,An application of non-uniform cellular automata for efficient cryptography,2013 IEEE Conference on Information and Communication Technologies, ICT 2013,V-,I-,PP-1200-1205,Y-2013

[4] Kumarave A., Rangarajan K.,Routing alogrithm over semi-regular tessellations,2013 IEEE Conference on Information and Communication Technologies, ICT 2013,V-,I-,PP-1180-1184,Y-2013

[5] P. Kavitha, S. Prabakaran "Designing a Feature Vector for Statistical Texture Analysis of Brain Tumor" International Journal of Engineering and Advanced Technology (IJEAT) ISSN: 2249-8958, Volume-8 Issue-5, June 2019

[6] Dutta P., Kumaravel A.,A novel approach to trust based identification of leaders in social networks, Indian Journal of Science and Technology,V-9,I-10,PP--,Y-2016

[7] Kumaravel A., Dutta P.,Application of Pca for context selection for collaborative filtering,Middle - East Journal of Scientific Research,V-20,I-1,PP-88-93,Y-2014

[8] Kumaravel A., Rangarajan K.,Constructing an automaton for exploring dynamic labyrinths,2012 International Conference on Radar, Communication and Computing, ICRCC 2012,V-,I-,PP-161-165,Y-2012

[9] P. Kavitha, S. Prabakaran "Adaptive Bilateral Filter for Multi-Resolution in Brain Tumor Recognition" International Journal of Innovative Technology and Exploring Engineering (IJITEE) ISSN: 
2278-3075, Volume-8 Issue-8 June, 2019

[10] Kumaravel A.,Comparison of two multi-classification approaches for detecting network attacks,World Applied Sciences Journal,V-27,I-11,PP-1461-1465,Y-2013

[11] Tariq J., Kumaravel A.,Construction of cellular automata over hexagonal and triangular tessellations for path planning of multi-robots,2016 IEEE International Conference on Computational Intelligence and Computing Research, ICCIC 2016,V-,I-,PP--,Y-2017

[12] Sudha M., Kumaravel A.,Analysis and measurement of wave guides using poisson method,Indonesian Journal of Electrical Engineering and Computer Science,V-8,I-2,PP-546-548,Y-2017

[13] Ayyappan G., Nalini C., Kumaravel A.,Various approaches of knowledge transfer in academic social network,International Journal of Engineering and Technology,V-,I-,PP-2791-2794,Y-2017

[14] Kaliyamurthie, K.P., Sivaraman, K., Ramesh, S. Imposing patient data privacy in wireless medical sensor networks through homomorphic cryptosystems 2016, Journal of Chemical and Pharmaceutical Sciences92.

[15] Kaliyamurthie, K.P., Balasubramanian, P.C. An approach to multi secure to historical malformed documents using integer ripple transfiguration 2016 Journal of Chemical and Pharmaceutical Sciences92.

[16] A.Sangeetha,C.Nalini,"Semantic Ranking based on keywords extractions in the web", International Journal of Engineering \& Technology, 7 (2.6) (2018) 290-292

[17] S.V.GayathiriDevi,C.Nalini,N.Kumar,"An efficient software verification using multi-layered software verification tool "International Journal of Engineering \& Technology, 7(2.21)2018 454-457

[18] C.Nalini,ShwtambariKharabe,"A Comparative Study On Differen Techniques Used For Finger - Vein Authentication", International Journal Of Pure And Applied Mathematics, Volume 116 No. 82017 , 327-333, Issn: 1314-3395

[19] M.S. Vivekanandan and Dr. C. Rajabhushanam, "Enabling Privacy Protection and Content Assurance in Geo-Social Networks", International Journal of Innovative Research in Management, Engineering and Technology, Vol 3, Issue 4, pp. 49-55, April 2018

[20] Dr. C. Rajabhushanam, V. Karthik, and G. Vivek, "Elasticity in Cloud Computing", International Journal of Innovative Research in Management, Engineering and Technology, Vol 3, Issue 4, pp. 104-111, April 2018.

[21] K. Rangaswamy and Dr. C. Rajabhushanamc, "CCN-Based Congestion Control Mechanism In Dynamic Networks", International Journal of Innovative Research in Management, Engineering and Technology, Vol 3, Issue 4, pp. 117-119, April 2018

[22] Kavitha, R., Nedunchelian, R., "Domain-specific Search engine optimization using healthcare ontology and a neural network backpropagation approach", 2017, Research Journal of Biotechnology, Special Issue 2:157-166

[23] Kavitha, G., Kavitha, R., "An analysis to improve throughput of high-power hubs in mobile ad hoc network", 2016, Journal of Chemical and Pharmaceutical Sciences, Vol-9, Issue-2: 361-363

[24] Kavitha, G., Kavitha, R., "Dipping interference to supplement throughput in MANET" , 2016, Journal of Chemical and Pharmaceutical Sciences, Vol-9, Issue-2: 357-360

[25] Michael, G., Chandrasekar, A.,'Leader election based malicious detection and response system in MANET using mechanism design approach", Journal of Chemical and Pharmaceutical Sciences(JCPS) Volume 9 Issue 2, April - June 2016

[26] Michael, G., Chandrasekar, A.,"Modeling of detection of camouflaging worm using epidemic dynamic model and power spectral density", Journal of Chemical and Pharmaceutical Sciences(JCPS) Volume 9 Issue 2, April - June 2016.

[27] Pothumani, S., Sriram, M., Sridhar, J., Arul Selvan, G., Secure mobile agents communication on intranet,Journal of Chemical and Pharmaceutical Sciences, volume 9, Issue 3, Pg No S32-S35, 2016

[28] Pothumani, S., Sriram, M., Sridhar , Various schemes for database encryption-a survey, Journal of Chemical and Pharmaceutical Sciences, volume 9, Issue 3, Pg NoS103-S106, 2016

[29] Pothumani, S., Sriram, M., Sridhar, A novel economic framework for cloud and grid computing, Journal of Chemical and Pharmaceutical Sciences, volume 9, Issue 3, Pg No S29-S31, 2016

[30] Priya, N., Sridhar, J., Sriram, M. "Ecommerce Transaction Security Challenges and Prevention Methods- New Approach" 2016 ,Journal of Chemical and Pharmaceutical Sciences, JCPS Volume 9 Issue 3.page no:S66-S68 .
[31] Priya, N.,Sridhar,J.,Sriram, M."Vehicular cloud computing security issues and solutions" Journal of Chemical and Pharmaceutical Sciences(JCPS) Volume 9 Issue 2, April - June 2016

[32] Priya, N., Sridhar, J., Sriram, M. "Mobile large data storage security in cloud computing environment-a new approach" JCPS Volume 9 Issue 2. April - June 2016

[33] Anuradha.C, Khanna.V, "Improving network performance and security in WSN using decentralized hypothesis testing "Journal of Chemical and Pharmaceutical Sciences(JCPS) Volume 9 Issue 2, April - June 2016.

[34] Anuradha.C, Khanna.V, "A novel gsm based control for e-devices" Journal of Chemical and Pharmaceutical Sciences(JCPS) Volume 9 Issue 2, April - June 2016

[35] Anuradha.C, Khanna.V, "Secured privacy preserving sharing and data integration in mobile web environments " Journal of Chemical and Pharmaceutical Sciences(JCPS) Volume 9 Issue 2, April - June 2016.

[36] Sundarraj, B., Kaliyamurthie, K.P. Social network analysis for decisive the ultimate classification from the ensemble to boost accuracy rates 2016 International Journal of Pharmacy and Technology

[37] Sundarraj, B., Kaliyamurthie, K.P. A content-based spam filtering approach victimisation artificial neural networks 2016 International Journal of Pharmacy and Technology83.

[38] Sundarraj, B., Kaliyamurthie, K.P. Remote sensing imaging for satellite image segmentation 2016 International Journal of Pharmacy and Technology8 3

[39] Sivaraman, K., Senthil, M. Intuitive driver proxy control using artificia intelligence 2016 International Journal of Pharmacy and Technology84.

[40] Sivaraman, K., Kaliyamurthie, K.P. Cloud computing in mobile technology 2016 Journal of Chemical and Pharmaceutical Sciences92.

[41] Sivaraman, K., Khanna, V. Implementation of an extension for browse to detect vulnerable elements on web pages and avoid click jacking 2016 Journal of Chemical and Pharmaceutical Sciences92.

\section{AUTHORS PROFILE}

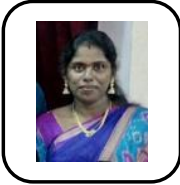

R.Kavitha Associate Professor, Department of Computer Science \& Engineering, Bharath Institute of Higher Education and Research, Chennai, India

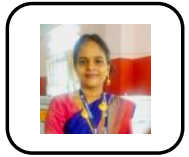

G. Kavitha , Assistant Professor, Department of Computer Science \& Engineering, Bharath Institute of Higher Education and Research, Chennai, India

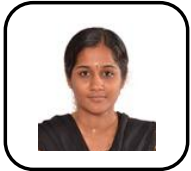

S.R. Srividhya, Assistant Professor, Department of Computer Science \& Engineering, Bharath Institute of Higher Education and Research, Chennai, India 